\title{
Anti-Glomerular Basement Membrane
}

\begin{tabular}{|l|l|l|}
\hline C.H. & Thompson \\
\hline S. & Kalowski \\
\hline
\end{tabular}

Renal Unit, Concord Hospital, Concord, Australia

Dr. S. Kalowski, Renal Unit, Concord Hospital, Concord 2139 N.S.W. (Australia)

Nephritis due to Hydralazine

\section{Dear Sir,}

Patient A.R., aged 48 years, presented with a 3-month history of anorexia, $7 \mathrm{~kg}$ weight loss, and a 5-day history of arthralgia involving the hands, knees, and ankles. Two days prior to presentation, he complained of a rash commencing on his right thigh and spreading over his body. The rash was initially pruritic macules which subsequently developed into crops of haemorrhagic blisters about $2 \times 2 \mathrm{~mm}$. He had no history of cough, dyspnoea, or haemoptysis. There was no history of dark urine or peripheral oedema.

He had a background of hypertension for 7 years, well controlled by hydralazine ( $100 \mathrm{mg}$ twice daily), pindolol (15 mg twice daily), and a combination diuretic of triam-terene (100 $\mathrm{mg}$ ) and hydrochlorothiazide (50 mg once daily). For 5 years, he had been taking $300 \mathrm{mg}$ allopurinol daily for gout.

On examination, his supine blood pressure was 130/90 mm Hg. Fundoscopy was normal. His spleen was palpable $2 \mathrm{~cm}$ below the left costal margin. There was no arthritis. Urinalysis showed +++ blood and +++ protein with 480,000 red blood cells $/ \mathrm{ml}$ (50\% dysmor-phic), and red cell casts were visible on urine microscopy.

Initial investigations showed a urea of $34.9 \mathrm{mmol} / 1$, creatinine $0.68 \mathrm{mmol} / 1$, sodium $136 \mathrm{mmol} / \mathrm{l}$, potassium $3.5 \mathrm{mmol} / \mathrm{l}$, chloride $105 \mathrm{mmol} / 1$, and bicarbonate $13 \mathrm{mmol} / 1$. Albumin was $26 \mathrm{~g} / \mathrm{l}$, haemoglobin $10.8 \mathrm{~g} / \mathrm{dl}$. Blood glucose was normal, urate was $0.65 \mathrm{mmol} / 1$. 24-hour urinary protein was $4.05 \mathrm{~g}$. C-reactive protein was $180 \mathrm{mmol} / \mathrm{l}$. Anti-nuclear factor was positive in a homogeneous pattern at a titre of 1:2,560. The double-stranded DNA was 20\% (normal being less than 20\%).

Anti-histone antibody was positive, and acetylator status was slow. Both $\mathrm{C} 3$ and $\mathrm{C} 4$ were depressed, circulating immune complexes were normal. The titre of anti-glom-erular basement membrane (GBM) antibody was positive by solid-phase radioimmunoassay.

A skin biopsy showed leucocytoclastic vasculitis with positive immunoñuorescence for IgG and fibrinogen. Renal biopsy showed crescentic glomerulonephritis with crescents involving almost all the glomeruli, with focal necrosis and scarring. Immunoñuorescence showed a very strong linear staining of capillary walls for IgG $(+++)$ and $\lambda$ light chains $(+)$. His chest X-ray was normal.

Hydralazine was ceased, and the patient was treated with daily plasmaphoresis as well as prednisone ( $2 \mathrm{mg} / \mathrm{kg} /$ day) and cyclophosphamide $(3 \mathrm{mg} / \mathrm{kg} /$ day $)$. After 2 weeks of therapy, the latter drug was ceased temporarily due to the white cell count dropping below normal. 
Cyclophosphamide was recommenced at $1 \mathrm{mg} / \mathrm{kg} /$ day, and prednisone reduced to $1 \mathrm{mg} / \mathrm{kg}$ second daily. On discharge, his creatinine was $0.41 \mathrm{mmol} / 1$, and urea $26.7 \mathrm{mmol} / 1$. After ceasing plasmaphoresis, the creatinine rose to $0.68 \mathrm{mmol} / \mathrm{l}$, on weekly plasmaphoresis his creatinine was stable at $0.54 \mathrm{mmol} / 1$, and the urea at $32.9 \mathrm{mmol} / \mathrm{l}$.

The rash and arthralgia rapidly resolved on ceasing hydralazine. The anti-GBM antibody disappeared after 1 week of treatment with plasmaphoresis and immunosup-pressives. Nine months later, it is still absent.

Although hydralazine-induced lupus involving the kidney is well described [1] anti-GBM renal disease secondary to hydralazine treatment has never been reported. The HLA association of hydralazine-induced lupus is

Anti-GBM Nephritis due to Hydralazine

239

DR 4 genotype [2], whilst that of over $80 \%$ of those with anti-GBM nephritis is DR 2 [3]. This patient's HLA typing is HLA DR2,--

There are certain environmental factors thought to trigger the production of anti-GBM antibodies. These include infective agents such as influenza A2 virus, and chemical substances such as hydrocarbon solvents. Peni-cillamine, particularly at high doses of over $1 \mathrm{~g}$ daily, has been associated with rapidly progressive glomerulone-phritis and lung haemorrhage - evidence, however, of linear staining of immunofluorescence on renal biopsy in these patients is lacking, granular $\mathrm{IgG}$ being noted in two cases [4].

The presence of granular IgG deposition and rapidly progressive glomerulonephritis has been well described with hydralazine $[1,5,6]$. This is the first time that the coexistence of linear staining of IgG on renal biopsy and anti-GBM antibody in the serum has been reported in the same patients [Bjorck, pers. commun.]. In the patient described above, the anti-GBM disease and hydralazine-induced lupus could be occurring as two separate diseases with similar times of onset, but as both conditions are rare, this is extremely unlikely.

We believe that this patient demonstrates the induction of anti-GBM renal disease by the administration of hydralazine.

References

Bjorck S, Svalander C, Westberg G: Hydralazine-associated glomerulonephritis. Acta Med Scand 1985;218:261-269.

Batchelor JR, Welsh KI, Tinoco RM, Dolleny CT, Highes GRV, Bernstein R, Ryan P, Naish PF, Aber GM, Bing RF, Russell GI: Hydralazine-induced systemic lupus erythematosus: Influence of HLA-DR and sex on susceptibility. Lancet 1980; 1107-1109.

Rees AJ, Peters DK, Amos N, Welsh KI, Batchelor JR: The influence of HLA-linked genes on the severity of anti-GBM antibody mediated nephritis, Kidney Int 1984;26:444-450.

Sternlieb I, Bennet B, Scheinberg IH: E > -Penicillamine induced Goodpasture's syndrome in Wilson's disease. Ann Intern Med 1975;82:673-676.

Ihle BH, Whitworth JA, Dowling JP, Kincaid-Smith P: Hydralazine and lupus nephritis. Clin Nephrol 1984;22:230-238.

Mason PD, Lockwood CM: Rapidly progressive nephritis in patients taking hydralazine, J Clin Lab Immunol 1986; 20: 151-153. 